\title{
THE SITUATIONAL BEHAVIOR ORIENTATION OF INSTRUCTIONAL SUPERVISION: A MULTISITE STUDY
}

\author{
Supriyono \\ Department of Education Management, Balitar Islamic \\ University, Indonesia \\ supriyono@unisbablitar.ac.id
}

\author{
Ali Imron \\ Department of Education Management, State \\ University of Malang, Indonesia \\ ali.imron.fip@um.ac.id
}

\author{
Imron Arifin \\ Department of Education Management, State \\ University of Malang, Indonesia \\ imron.arifin.fip@um.ac.id \\ Kusmintardjo \\ Department of Education Management, State \\ University of Malang, Indonesia \\ kustar_um@yahoo.co.id
}

\begin{abstract}
This study was aimed at disclosing the instructional behavior orientation at public middle schools in Blitar, East Java, Indonesia. The focuses of this study were: (1) design of the instructional supervision behavior orientation, (2) implementa-tion of the instructional supervision behavior orientation, and (3) outcomes of the instructional behavior orientation. This research employed qualitative approach with multisite study design. Data were collected by using interview, documen-tation, and obser-vation. Data were analyzed by using the combination of inter-active and modified analysis. Results of this research revealed that the instruc-tional supervision behavior orientation turned out to be the situational orientation of instructional behavior comprising 4 (four) orientation, i,e. Showing directively, Showing persuasively, Participating interactively and Trusting delegative-ly. Such orientations turned out to significantly relate to teachers' competency and performance enhancement.
\end{abstract}

Keywords: instructional supervision; behavior orientation, public middle school

\section{INTRODUCTION}

In persuit of smartenning the nation life through the obligation of participating in the basic education for all Indonesian citizens, quality education has become the primary attention of policy makers and educators. The main factor influencing the quality of edcation has been identified as the teachers quality. Therefore, teachers professional development has been very essential. One of the professional support which has been considered successful in developing teachers' quality is instructional supervision. Instructional supervision has become one of the types of teachers' professional development [1], [2], [3], [4], [5], [6], [7], [8], [9], [10]. Researches has shown that instructional supervision has played important roles in education. Zepeda (2007) founded that instructional supervision was ighly needed, however, it was not implemented effectively [11]. Paynes founded that teachers were highly expected to be involved in all aspects of instructional supervision by collaborating with the administrators. Kutsyuruba found out that teachers highly needed having instructional supervision which fulfill their professional needs [12].

Karyono found out that instructional supervision was meaningful due to having positive relation with the teachers' performance [13]. Factually, there was interesting phenomenon at middle schools in Blitar city, East Java Indonesia. The instructional supervision involved principals, vice principals, senior teachers, and subject matters supervisor from the municipal department of education and culture. Unique supervisory behavior orientation turned out to be obvious which relatively different from what the socalled the Glickman's directive controlled and informational, non-directive, and collaborative . The practices likely had the elements of the so-called Hersey, Blanchard, and Johnson situational leadership
[15]. There were likely four types of the instructional supervision behavior orientation applied by supervisors at meddle schools in Blitar and were obviously related to the teachers' competence and performance enhancement ass seen in the preliminary study. To disclose this phenomenon, the researchers conducted this research which specifically looking over behavior orientation of instructional supervision.

Based on the contexts, this research was aimed at disclosing the behavior orientation of instructional supervision and was formulized into the following focuses: (1) design of the instruc-tional supervision behavior orientation, (2) implementation of the instructional supervision behavior orientation, and (3) out-comes of the instructional behavior orientation. This research was expected to highly benificial for minicipal education department authority, supervisors, principals, and teachers for references of the professional reflection to innovate instructional supervision best practices and for the universities to make used of this research results for developing appropriate educational trainings and programs to enhance the quality of education through teachers' professional developmenr using supervision.

\section{LITERATURE REVIEW}

Instructional supervision has become important attention since 800 at which year and forward up to the 1400 s, there appeared the so-called close supervision on relegious and moral development in England [6]. In 1630 s, the similar kinds of supervisions appeared in the New England which was aimed at controlling the moral and religious education. In 1800s, the instructional supervision moved to the so-called supervison of instruction to oversee the compliance of school operation in local school distric and general supervision as well as special supervision to help education superintendent of the primary and middle schools to 
ensure the classroom instruction and subject matters teaching [6].

Supervision in these years were called by Lucio and McNail as administrative inspection [16]. In 1910s to $1920 \mathrm{~s}$, the instructional supervision moved to supervision to lead and help teachers [17], in [6], Supervision for improvement of Instruction with visitation, observation, and teachers' rating [19], in [6]. In these era, the instructional supervisions were called to be supervision by specialists which focused on overseeing the subject matters instruction [16]. In 1920s to $30 \mathrm{~s}$ to $60 \mathrm{~s}$, there appeared supervision for improvement of teaching act that was employed to improve teaching and learning activities (Burton, 1922, in [6], supervision for stimulations of instruction to stimulate teaching and learning activities [17], in [6], and scientific supervision as the tool to improve teaching and learnning activities by using scientific methods [6]. In this era, Lucio and McNeil mentioned as the democratic human relation [16]. Meanwhile,
Wiles and Bondi stated as the cooperative supervision [20].

In 1930s-1960s, there also appeared supervision as group processes [6] which enforced to the personality to influence group learning in the classrooms, supervision as indidenous instructional team [6] which used internal master teachers, creative supervision [6] which employed creative method, clinical supervision [21]; [22]; and [14]. Such supervisory development improved years after years up to the innovation of Glickman, Gordon, and Ross-Gordon [14] with the socalled the SuperVision as Developmental. The latter type of instructional supervision focused on the teachers' professional development through the operational assistance using supervision which outlined the compelete guides of dupervisors requirements, functions, tasks, unification of target factors and outcomes. Which can be shown in the following pictures.

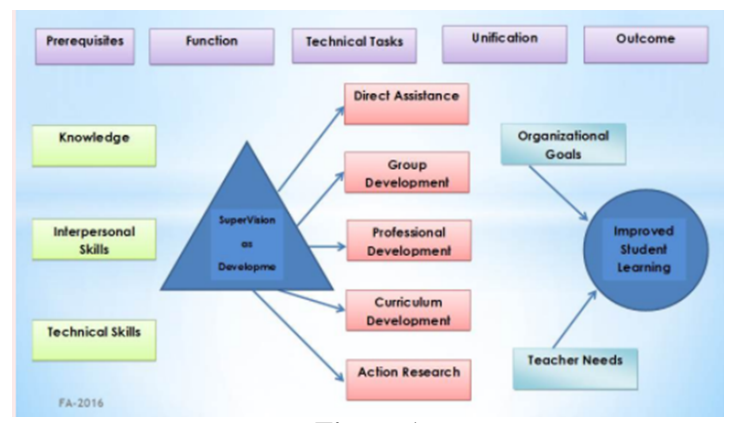

Figure 1

Supervision as Developmental for

Successful Schools adapted from Glickman, Gordon, and Ross-Gordon [14]

To effectively attain the outcomes, Glickman, Gordon, and Ross-Gordon introduced the so-called four types of Instructional supervisory behavior orientation [14]. These super-visory behavior orientation included directive controlled, directive informational, non directive, and collaborative behavior orientation. The behavior continum of these behavior tended to use responses such as listening, clarifying or explaining answers, encouraging, reflecting, presenting, problem solving, negotiating, demonstratting, directing, and reinforcing [2]. Each of the orientation has different continum. The directive controlled and informational tend to work on the part of the supervisor, the non directive behavior orientation tends to work on the part of the teachers, and the collaborative behavior orientation tend to work on the part of supervisors and teachers. These shall be managed according to the teachers condition for maximum outcomes. To be more effective Glickman advised to combined with the analysis of teachers' commitment and teachers' abstraction comprising teachers of quadrant 1, quadrant 2, quadrant 3, and quadrant 4 [2]. Looking at the work of using theachers' condition and behavioral style, the researcher found out to have comparative method of approaching teachers as followers by using situational [15] by using flowers readiness and leadership styles having the so-called telling, selling, participating, and delegating for the readiness 1 readiness 2, readiness 3 , and readiness 4 . Both methods employed the teachers or followers development.

\section{METHODS}

Based on the reserch focuses, the researchers explored and describe natural phenomenon to disclose what happens on the instructional supervisory behavior orientation in the contexts of research which were three different middle schools in Blitar, East Java, Indonesia. This research was descriptive, meaningful, and unintentionally focused on the quantitative data. Therefore, this employed qualitative approach [23] or qualitaitve research [24], or descriptive qualitative study [25]. Due to having three different sites to research, this employed a multisite study [26]. The samples were taken by using purposive random sampling with snow balling techniques and concisted of distric supervisors, principals, senior teachers, teachers, and students of middle schools in Blitar, East Java, Indonesia. Data were collected by using interview, documentation, and observation. The interview was a type of in depth interview.

The documentation concerned with the documentation of instructional supervision in the three sites. Whereas, the observation concerned with the descriptive, focused, and and selective observation. 
Open ended with recording method was used for the interview and for the purposes of data reduction and analysis interview contact sumary format was used [27]. The contact summary was also used for documentation. Besides contact summary, field notes were used for observation, Codings were also used for the purpose of data collection and data analysis. The data analysis was done by using interactive method [27], and inductive modified analysis [28]. To ensure reliability and validity, measures of credibility, dependability,confirmability, transferability, and transferability were employed by using triangulation, audit trail, thick description, and process reflection were done. The analysis consist of within site analysis and cross site analysis. The following was the research framework.

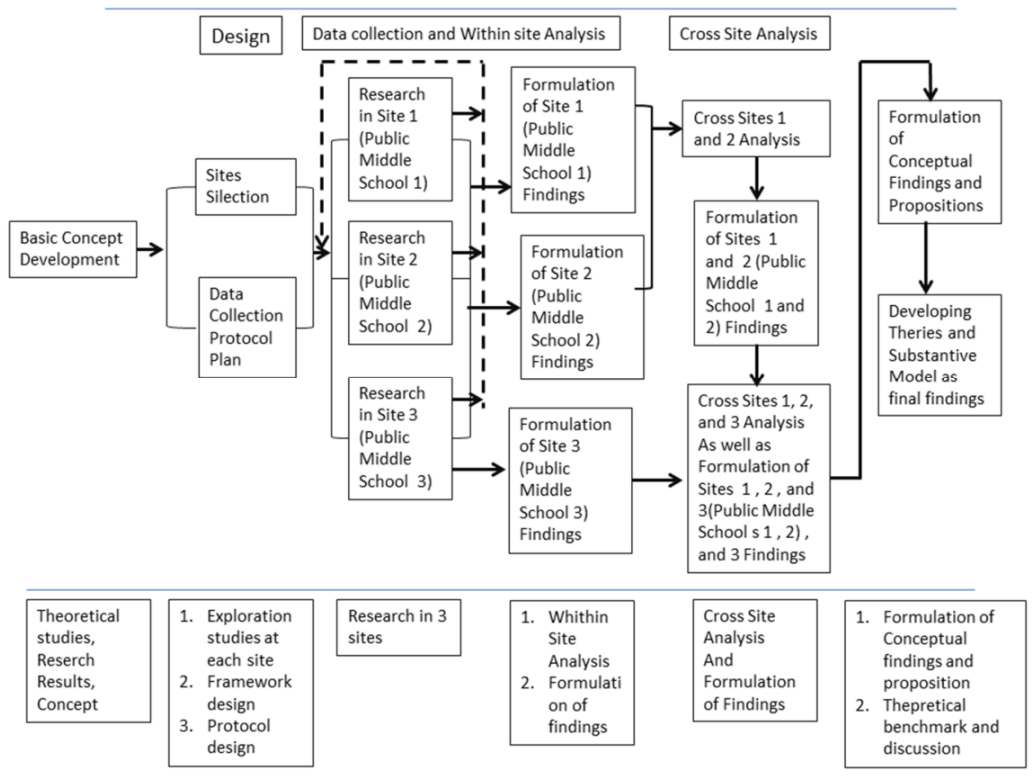

Figure 2

Framework of the research design

\section{RESULTS AND DISCUSSIONS}

The research revealed that there were four types of instructional super-vision behavior orientation applied at middle schools in Blitar. Each of the orientation had unique supervisory communiction action the supervisors. Each of them was applied by analyzing the condition of teachers in terms of the seniority, willingness \& motivation, and capability. Using the combination of SuperVision as developmentl and situation-al leadership refefences, the instructional behavior orientaion styles could be fromulated as situational instructional super-vision behavior orientation with four types namely showing directively, showing persuasively, participating interactively, and trusting delegatively. In terms of the seniority, willingness \& motivation, as well as capability, the teachers' condition was devided into four types, which were: (1) Type 1 were those who were junior and/or senior teachers having low motivation and willingness and low capability (for the senior teachers, this mostly concerned with new knowledge and technical skills required), (2) Type 2 were those who were junior and/or senior teachers having high willingness and motivation with inadequate capability, (3) Type 3 were those who were mostly senior teachers, motivated, willing, and capable with needs of guidance, and (4 Type four were those who were senior teachers higly motivated, willing, and highly capable.
These were applied in the following model. The research results also showed that the practice of situational instructional supervision behavior orientation related effectively on the: (1) increase of teachers' motivation, willingness, and commitment, (2) increase of teachers capabi-lity in terms of the competences and performances, and (3) atainment of better learning outcomes.

Looking at these results, the situational instructional behavior orientation considered the teachers background on the seniority, motivation, willingness, and capability. These may similar with what Glickman said as commitment and astraction [2]. However, these were different in nature and had similarity in determining the knowledge as a part of cabality which was the same as abstrac-tion. In terms of the teachers anlysis, these were likely similar with the so called readiness as stated by Hersey, Blanchard, and Johnson as readiness in situational leadership; however, these were different in nature [15]. The identification of the willingness and motivation were similar to the situational leadership. Mean-while, the four types of the orientation and the communiction actions were likely similar with the so called directive controlled, directive informational, non-directive, and collaborative as in the SuperVision as developmental [2]. However, these were different in nature due to the consideration were the practical techniques looking at the real situation at the schools. 
Table 1

Continum of Situational Instructional Supervision Behavior Orientation

\begin{tabular}{|c|c|c|c|c|}
\hline \multicolumn{2}{|c|}{$\begin{array}{c}\text { Teachers' Seniority, } \\
\text { Motivation, and Capability }\end{array}$} & \multicolumn{2}{|c|}{$\begin{array}{c}\text { Instructional Supervision } \\
\text { Behavior Orientation }\end{array}$} & \multirow[b]{2}{*}{$\begin{array}{l}\text { Supervisory } \\
\text { communication actions } \\
\text { 1. checking instructional } \\
\text { administration document, } \\
\text { 2. asking teachers on the } \\
\text { problems and followed of } \\
\text { of the previous feedback } \\
\text { 3. identifying problems } \\
\text { and showing teachers } \\
\text { how to solve the } \\
\text { problems } \\
\text { 4. giving examples of the } \\
\text { way out to the teachers' } \\
\text { problems } \\
\text { 5. listening to teachers on } \\
\text { proposal of the follow up } \\
\text { 6. taking decision of the } \\
\text { follow up } \\
\text { 7. agreeing on the follow } \\
\text { up of the improvement. }\end{array}$} \\
\hline Type 1 & $\begin{array}{l}\text { Junior teachers } \\
\text { and/ or Senior } \\
\text { teachers having } \\
\text { low motivation, } \\
\text { low willing-ness, } \\
\text { low capa-bility } \\
\text { (Usually the } \\
\text { senior teachers } \\
\text { experienced } \\
\text { regression on the } \\
\text { commit-ment } \\
\text { duw to new } \\
\text { things that they } \\
\text { were incapable) }\end{array}$ & Type 1 & $\begin{array}{l}\text { Showing } \\
\text { directively }\end{array}$ & \\
\hline Type 2 & $\begin{array}{l}\text { Junior teachers } \\
\text { and/or Senior } \\
\text { teachers having } \\
\text { high motivation } \\
\text { and willingness } \\
\text { with inadequate } \\
\text { capability. } \\
\text { Teachers usually } \\
\text { needed guidance } \\
\text { for new things. }\end{array}$ & Type 2 & $\begin{array}{l}\text { Showing } \\
\text { persuasively }\end{array}$ & $\begin{array}{l}\text { 1. together with teachers } \\
\text { cecking instructional } \\
\text { administration document, } \\
\text { 2. listening to teachers on } \\
\text { telling the problem they } \\
\text { faced } \\
\text { 3. giving ideas and } \\
\text { responding on the } \\
\text { problem faced by } \\
\text { teachers } \\
\text { 4. listening to teachers to } \\
\text { give reasons why the } \\
\text { problems happenned and } \\
\text { identify the resolution } \\
\text { 5. giving advise on } \\
\text { resolution and persuading } \\
\text { to choose options of the } \\
\text { solutions, } \\
\text { 6. together with teachers } \\
\text { approving the } \\
\text { resolution }\end{array}$ \\
\hline Type 4 & $\begin{array}{l}\text { Mostly senior } \\
\text { teachers having } \\
\text { high motivat-ion, } \\
\text { high willingness, } \\
\text { and high } \\
\text { capability }\end{array}$ & Type 4 & $\begin{array}{l}\text { Trusting } \\
\text { delegatively }\end{array}$ & $\begin{array}{l}\text { 1. together with teachers } \\
\text { checking instructional } \\
\text { administration document, } \\
\text { 2. listening to teachers on } \\
\text { presenting teachers } \\
\text { problem and giving } \\
\text { opinion on the problems, } \\
\text { 3. listening to teachers on } \\
\text { identifying the resouktion } \\
\text { and giving options on the } \\
\text { resolution choices, } \\
\text { 4. listening teachers making } \\
\text { alternative solutions and } \\
\text { giving opinions on the } \\
\text { solution, } \\
\text { 5. discussing the } \\
\text { resolutions, } \\
\text { 6. agreeing on the options } \\
\text { of the resolutions, } \\
\text { 7. agreeing on the follow up }\end{array}$ \\
\hline
\end{tabular}

\section{CONCLUSION AND SUGGESTION}

This research concluded that the instructional super-vision orientation that was developed on the basis of the teachers seniority, willingness, motivation, and capabiliy and using appropriate situasional teacherssupervisors connection communication actions provide professional assistance that effectively related to the teachers' increase in motivation, willingness, commitment, capability in terms of the competen-ces and performances as well as the attainment of the better learning outcomes.

\section{ACKNOWLEDGMENT}

High appreciation goes to official supervisors, principals, and teachers of Public Middle Schools in Blitar, East Java, for the cooperation to complete this research. The Researchers highly appreciate Prof. Dr. Bambang Budi Wioyono, M.Pd and Prof. Dr. Agus 
Suman, DEA for their professional feedback and review.

\section{REFERENCES}

[1] A. Imron. 2007. Pendekatan Ilmiah Supervisi. Pendekatan Artistik, Supervisi Pengajaran, Perilaku Direktif Supervisi Pengajaran. In Burhannuddin, Hendyat Sutopo, Ali Imron, Maisyaroh, and Nurul Ulfatin, (Ed.). 2007. Supervisi Pendidikan dan Pengajaran: Konsep, Pendekatan, dan Penerapan Profesional. Malang: Faculty of Education, State University of Malang, pp 6.

[2] C. D. Glickman. 1981. Developmental Supervision: Alternative Practices for Helping Teachers Improve Instruction. Alexandria, Virginia: ASCD., pp 3.

[3] D. H. Suhardan. 2010. Supervisi Profesional: Layanan dalam Meningkatkan Mutu Pembelajaran di Era Otonomi Daerah. Bandung: Alfabeta, pp 40.

[4] H. Burhanudin. 2007. Supervisi Dalam Rangka Pembinaan Profesional. In Burhanuddin, Sutopo, H., Imron, A., Maisyaroh, Ulfiatin, N., (Ed.). 2007. Supervisi Pendidikan dan Pengajaran: Konsep, Pendekatan, dan Penerapan Profesional. Malang: Faculty of Education, State University of Malang.

[5] M. Pidarta. 2009. Supervisi Pendidikan Kontekstual. Jakarta: Penerbit Rineka Cipta, pp 3.

[6] J. M. Gwyn. 1961. Theory and Practice of Supervision. Toronto: Dodd, Mead, \& Company, pp 4- 15.

[7] Maryono. 2011. Dasar-dasar \& Teknik Menjadi Supervisor Pendidikan. Yogyakarta: Arusmedia, pp 2328.

[8] P. A. Sahertian. 2008. Konsep Dasar dan Teknik Supervisi Pendidikan dalam Rangka Pengembagan Sumber Daya Manusia. Jakarta: Penerbit Rineka Cipta, pp 2.

[9] S. J. Zepeda. 2007. Instructional Supervision: Applying Tools and Concepts. Larchmont, NY: Eye on Education, Inc, pp 29.

[10] W. Mantja. 2010. Profesionalisasi Tenaga Kependidikan: Manajemen Pendidikan dan Supervisi Pengajaran: Kumpulan Karya Tulis Terpublikasi. Malang: Penerbit Elang Mas.

[11] E. T Paynes, E.T. 2010. Implementing Walkthroughs: One School's Journey. Unpublised Dissertation. Falls Church, VA :Virginia Polytechnic Institute and State University.

[12] B. Kutsyuruba. 2003. Insrtructional Supervision: Perceptions of Canadian and Ukrainian Beginning High-School Teachers. Unpublihed Thesis. Saskatoon: Saskatchewan.

[13] H. Karyono, 2007. Supervisi Pengajaran Untuk Meningkatkan Profesionalisme Guru di Sekolah Dasar:Studi Multi Kasus di SD Laboratorium Sumber Ilmu, SDN Sekar Arum I, SDK Sang Surya, dan SDN Madukoro VI. Unpublised Dissertation. Malang: State University of Malang.

[14] C. D. Glickman, S. P. Gordon, \& J. M. Ross-Gordon, 2009. Supervision and Instructional Leadership: A Developmental Approach. Boston: Pearson.

[15] P. Hersey, K. H. Blanchard, \& D. E. Johnson 1996. Management of Organizati-onal Behavior: Utilizing Human Resources. New Jerssey: Prentice Hall.

[16] W. H. Lucio., \& J. D. McNeil. 1979. Supervision in Thought and Action. New York: McGraw-Hill Book Co.

[17] E. P. Cubbery. 1916. Public Schools Administration: A Statement of the Fundemental Principles Underlying
The Organization and Administration of Public Education. Boston: Houghton Mifflin.

[18] C. A. Wagner. 1921.Common Sense in School Supervision. Melwaukee: Bruce Publishing Company.

[19] C. E. Scott.1924. Educational Supervision. Melwaukee: Bruce Publishing Company.

[20] J. Wiles, \& J. Bondi, J. 1986. Supervision:A Guide to Practice. Charles E, Merril Publishing Company. Columbus, Ohio: A Bell and Howell Company.

[21] M. L. Cognan. 1973. Clinical Supervision. Boston: Houghton Mifflin.

[22] R. Goldhammer, R. H. Anderson, \& R. J. Krajewski. 1993. Clinical supervision: Special Methods for the Supervision of Teachers. New York: Holt, Rinehart and Winston.

[23] S. B. Merriam. 1998. Qualitative Research and Case Study Application in Education. San Fransisco: JosseyBass Publishers, pp 23.

[24] R. J. Klimoski.1978. Simulation Methodologies in Experimental Research on Negotiation By Representative. Journal of Conflict Resolution, 22, 6177.

[25] Supriyono. 1996. An Integrated Meaning-Form Focused Instructional Framework With Reference to Task-Based Methodology For The Implementation of The 1994 EFL Syllabus For Primary Schools in East Java. Unpublished Thesis. Bundoora: La Trobe University.

[26] S. A. Kalaian. 2003. Meta-analysis Methods for Synthesizing Treatment Effects in Multisite Studies: Hierarchical Linear Modeling (HLM) Perspective, Practical Assessment, Research \& Evaluation, 8(15). Retrivied May, 2, 2016, from http://PAREonline.net/getvn. asp?v= 8\&n=15).

[27] R. C. Bogdan, \& S. K. Biklen. 1998. Qualitative Research for Education: An Introduction to Theory and Methods. London: Allyn and Bacon, Inc.

[28] Miles, M. B., \& Huberman, A. M. 1987. Qualtitative Data Analysis: A Sourcebook of New Methods. Baverly Hill, CA: Sage Publication, Inc. 